\title{
EGY FOLYÓIRAT ADATAIT TARTALMAZÓ ADATBÁZIS KONCEPCIÓS MODELLJÉNEK ELKÉSZÍTÉSE
}

\author{
Hampel György
}

\begin{abstract}
Absztrakt: A Jelenkori társadalmi és gazdasági folyamatok című folyóiratban számos magyar és külföldi szakember színvonalas publikációja jelent meg 2006 óta. Annak érdekében, hogy az eddig megjelent, illetve a későbbiekben megjelenő számokban található információk hatékony módon kinyerhetők legyenek, egy adatbázis létrehozásának ötlete merült fel, amelynek megvalósításához az első lépés a koncepcionális modell elkészítése, amely jelen cikk tárgya. A létrehozott egyed-kapcsolat modell - amely 3 egyedhalmazt, 39 attribútumot és 3 kapcsolatot tartalmaz - alkalmas arra, hogy relációs sémává konvertálva, majd SQL-alapú adatbázis-kezelőben megvalósítva kiszolgálja a folyóirattal kapcsolatos jelenlegi információs igényeket.
\end{abstract}

\begin{abstract}
Since 2006, several Hungarian and foreign experts have published high-quality publications in the Journal of Contemporary Social and Economic Processes. To efficiently extract the information from the publications, the idea to create a database arose. The first step to achieve this is to prepare a conceptual model which is the subject of the current article. The created entityrelationship model includes 3 entity sets, 39 attributes and 3 relationships. This model can serve the current information needs related to the journal when converted to a relational schema and then implemented in an SQL-based database system.
\end{abstract}

Kulcsszavak: adatbázis, adatmodell, egyed-kapcsolat modell, Jelenkori társadalmi és gazdasági folyamatok folyóirat, Szegedi Tudományegyetem, Mérnöki Kar

Keywords: database, data model, entity-relationship model, Journal of Contemporary Social and Economic Processes, University of Szeged, Faculty of Engineering

\section{Bevezetés}

A Szegedi Tudományegyetem Mérnöki Karának Ökonómiai és Vidékfejlesztési Intézete gondozásában elöször 2006 novemberében jelent meg az intézet oktatóinak lektorált tudományos publikációit tartalmazó nyomtatott évkönyv (ISBN: 978-963482-799-3). Ahogy a kötet akkori főszerkesztője - Dr. Gulyás László PhD. - akkor írta, az intézet oktatói a kötetben bemutatják a kutatási témájuk egy kis darabját (Gulyás, 2006). Ezt követően 2007 decemberben jelent meg először „Jelenkori társadalmi és gazdasági folyamatok" címmel az újabb kötet, még szintén tudományos évkönyvként (ISSN: 1788-7593), és ahogy - Dr. Gulyás László PhD. és Dr. Gál József PhD. - főszerkesztők is jelzik az előszóban, ekkor már az intézet külső óraadóinak cikkei is helyet kaptak az évkönyben (Gulyás-Gál, 2007). 2008 öszén tovább bővült a a szerzők köre: négy szerzői csoportról beszélhetünk (GulyásGál, 2008): az Ökonómiai és Vidékfejlesztési Intézet munkatársai, óraadói mellett megjelentek a hazai és külföldi szerzők cikkei is. Mára már gyakorlattá vált az is, hogy a kar hallgatói témavezetőikkel együtt jelentetnek meg egy-egy cikket: PanyorSzebelédi (2018), Lendvai-Koppány (2018), Zsótér-Bagi (2020) csak néhány példa a teljesség igénye nélkül.

A 2009-ben megjelentetett 4. évfolyam 1. száma már „folyóirat”-ként nevezi meg magát (lásd: 1 . ábra) és a magyar nyelvüek mellett tartalmaz idegen nyelvü cikkeket is. 
1. ábra: A folyóirat borító címoldala 2009. (4. évf. 1. szám)

A grafikai terv Mónus Szilvia munkája.

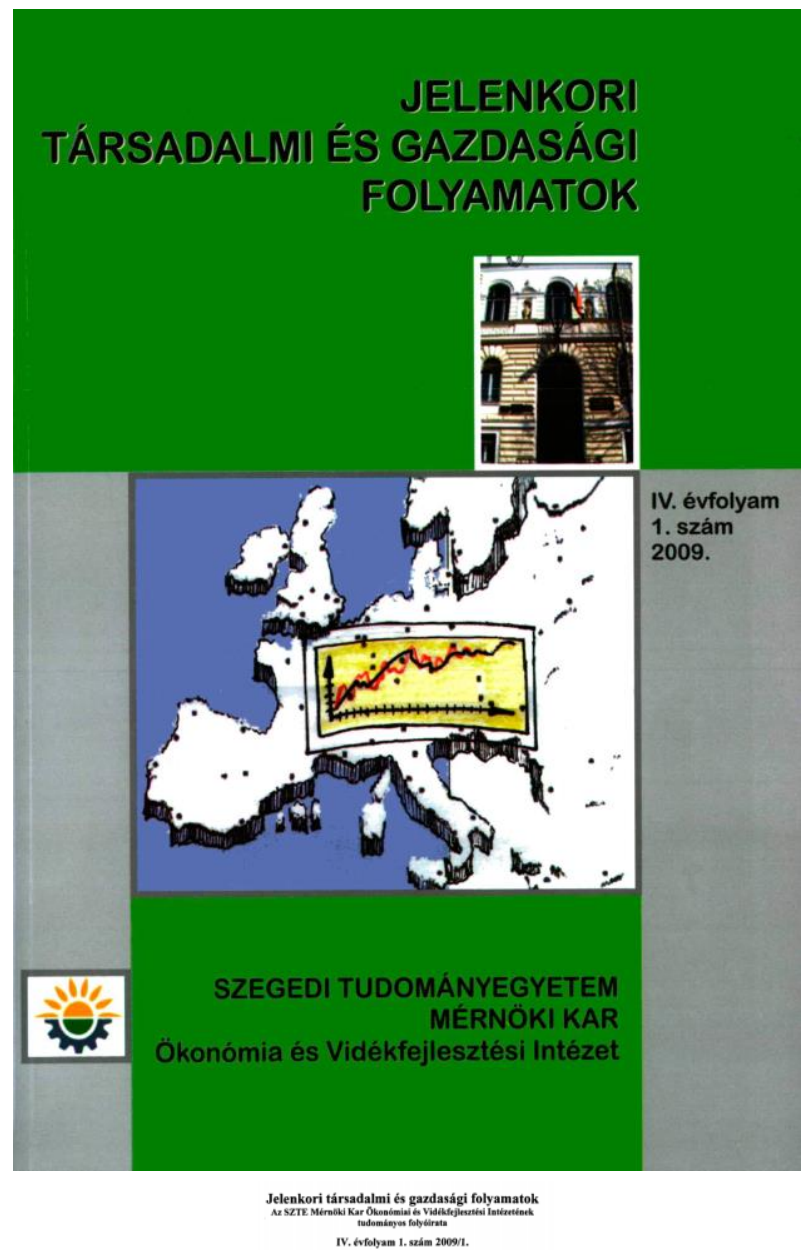

Forrás: Gulyás-Gál, 2008

Az azóta eltelt időben 2020. első feléig megjelent összesen 24 szám (ebbe beleszámítva a 2006. és 2007. évi évkönyvet is), a folyóirat jelenleg (2020. augusztusában) a 15. évfolyamánál tart és a 2019. évi (14. évfolyam) 3. szám már online ISSN számmal is rendelkezik (ISSN: 2676-9867).

Az eltelt évek alatt számos és szerteágazó tudományterületről származó cikk kapott helyet a folyóiratban; a 2020. 1. számot is figyelembe véve 454 publikáció jelent meg 456 különböző szerzőtől (illetve, ha figyelembe vesszük, hogy egyes szerzők többször is publikáltak és egyes cikkeknek több társszerzője is volt, a szerzők száma - az ismétlődéseket is beleszámolva - 848).

Dr. habil. Kis Krisztián felelős szerkesztő kitartó munkájának eredményeként 2020. évtől már MTA besorolással rendelkező minősített folyóiratról beszélhetünk (IX. Gazdaság- és Jogtudományok Osztály, Demográfiai Osztályközi Állandó Bizottság), amelyet az MTMT a tudományos folyóiratok között referál (Kis, 2020). 
A töretlen fejlödést látva merült fel annak a gondolata, hogy létre kellene hozni egy folyóirat adatbázist, amely könnyebbé teheti a folyóirat példányaiból származó lényeges információk kinyerését.

A megvalósítandó feladat tehát egy adatbázis megtervezése magas szintü modellel (egyed-kapcsolat modellel), a logikai adatmodell elkészítése (relációs adatmodellel), végül az adatbázis tényleges megvalósítása (SQL relációs adatbáziskezelövel).

Ebben a publikációban a folyóirathoz kapcsolódó adatbázis koncepcionális megtervezésével, vagyis az egyed-kapcsolat modell elkészítésével foglalkozom.

Az átgondolt tervezés előnyei:

- könnyen megérthető formában mutatja az adatbázis szerkezetét, az adatcsoportokat és azok kapcsolatait, valamint az esetleges korlátozásokat,

- mind a felhasználóknak, mind pedig a programozóknak újabb ötleteket ad,

- mivel könnyen megérthető, segíti a felhasználó és a programozó közötti párbeszédet,

- olyan terv, leírás, amit az adatbázis-kezelő rendszer kiválasztásával, módosításával nem kell megváltoztatni.

\section{Az adatbázis és logikai szintü megtervezése egyed-kapcsolat modellel}

\subsection{Adatbázis}

Az adatbázis az adott területet jellemző adatokból, az adatok típusát és a kapcsolatokat leíró metaadatokból és az adatkezelő rendszerből áll (Tímár et al. 1997) vagy

„...véges számú egyed-előfordulásnak, azok egyenként is véges számú tulajdonságértékének és kapcsolat-előfordulásainak az adatmodell szerint szervezett együttese." (Halassy, 1994: 38p.) vagy

„egy olyan integrált adatszerkezet, mely több különböző objektum elöfordulási adatait adatmodell szerint szervezetten perzisztens módon tárolja olyan segédinformációkkal, ún. meta-adatokkal együtt, melyek a hatékonyság, integritásőrzés, adatvédelem biztosítását szolgálják.” (Kovács, 2004: 24p.)

És még lehetne sorolni jónéhány meghatározást, hiszen az adatbázisra nincs egységesen elfogadott definíció.

Egy adatbázis létrehozásának és használatának több előnye lehet, így (Kroenke, 2006; Kacsukné-Kiss, 2009):

- egységes, logikailag tiszta adatszerkezet,

- az adatok és az azokat kezelő programok függetlenek egymástól, ebből következően bármelyik módosítható a másik módosítása nélkül,

- $\quad$ az adatok flexibilis módon, könnyen lekérdezhetök.

\subsection{Koncepcionális modell}

Az adatbázist megtervezése során először koncepcionális modellt készítünk, majd az alapján készül el a logikai modell és csak ezt követi a tényleges, fizikai megvalósítás (jó esetben). 
A koncepcionális adatmodell olyan eszközök gyüjteménye, amelyek célja a valóság leírása olyan módon, hogy a létrehozott modell legyen képes a valóságról feltett kérdések megválaszolására (Watson, 2006). Ez a modell nem foglalkozik az adatok szerkezetével és a fizikai tárolás problémáival sem.

A koncepcionális (magas szintü) adatmodell létrehozása elméletileg is és gyakorlatilag is jelentős szerepet tölt be az adatbázis-tervezési folyamatban (Dey et al., 1999). A koncepcionális sémák tartalmazzák az egyedek halmazát, azok jellemzőit, a kapcsolatokat és a korlátozásokat. Emellett szemléletes módon, ábrákkal mutatják be az adatbázis logikai felépítését; nem hozzáértő számára is érthető formában szemléltetik a valóság egy részét modellező adatbázist (Tímár et al., 1997). Természetesen, mint mindent, ezt is el lehet rontani; a hibás tervezéshez hozzájárul a modellező eszközök nem megfelelő alkalmazása, a felhasználók és az adatbázis-tervezők képzelőerejének korlátai, a felhasználók és az adatbázis-készítő szakemberek eltérö látásmódja és problémamegközelítése (Badia-Lemiere, 2011), valamint - bár a modell egyszerü - az lényeges, hogy a modellezö tanulja meg/rendelkezzen azzal a képességgel, ami biztosítja számára a szükséges objektumok és kapcsolataik helyes azonosítását (Watson, 2006).

Akik az adatmodellezésben még nem kellően járatosak (például egyetemi hallgatók, akik adatbázis-tervezést tanulnak) Watson (2006) szerint a következő hibákat követik el leggyakrabban:

- nem ismerik fel, hogy egy attribútumnak vélt valami az valójában egyed,

- nem képesek egyedeket általánosítani és egyedhalmazhoz rendelni,

- nem ellenőrzik a kapcsolatot mindkét irányból, így a kardinalitás (összekapcsolódó egyedek számossága) megállapítása téves,

- esetleges kivételeket figyelmen kívül hagynak.

\subsection{Tervezési alapelvek}

Az adatbázis megtervezése során néhány hasznos alapelvet érdemes megfontolni, ezek: (Ulman-Widom, 2009)

1. Valósághü modellezés: Az egyedhalmazoknak, az attribútumoknak, valamint a kapcsolatoknak tükrözniük kell a valóságot (nem lehet például a CIKK egyedtípusnak tudományos fokozat attribútuma).

2. Rendundancia-mentesség (vagy legalább arra való törekvés): Törekedni kell arra, hogy minden adat lehetőleg csak egyszer szerepeljen. Például a szerző nevét - mint attribútumot - ne tároljuk el a CIKK és egyúttal a SZERZÖ egyedhalmazban is. Ezzel különböző (beviteli, tárolási, frissítési, és törlési) anomáliáknak nevezett, az adatbázis használatát és karbantartását nehezítő problémákat kerülhetünk el (Halassy, 2000). Ugyanakkor elöfordulhatnak olyan esetek, amikor célszerüségi okokból mégis rákényszerülhetünk a redundáns adattárolásra - ez az adott helyzettől, igényektől, adatbáziskezelörendszertöl függ.

3. Egyszerüség: Ne vegyünk fel több egyedhalmazt, attribútumot és kapcsolatot annál, mint amennyi feltétlenül szükséges. Például a SZERZÖ esetén felesleges felvenni a szemszín attribútumot (bár kétségtelenül érdekes 
lenne annak megvizsgálása, hogy a populációban leggyakrabban előforduló barna színhez képest van-e eltérés a szerzőknél és ha igen, az milyen mértékü).

4. Megfelelő kapcsolatok kiválasztása: Az egyedhalmazokat - kiváltképpen, ha sok van belölük - sokféleképpen kapcsolhatjuk össze. Általában nem célszerü az összes kapcsolatot létrehozni, mert az a már korábban említett anomáliákhoz vezethet és csak megnehezíti (vagy akár el is lehetetlenítheti) az adatbázis kezelését. Az(oka)t a kapcsolato(ka)t célszerü feltüntetni, amelyek az adott feladat megoldása szempontjából szükségesek és ehhez tudnunk kell elöre, hogy valójában mit is várunk el az adatbázistól. A SZERZÖ és a CIKK között például több-a-többhöz kapcsolatot célszerü kialakítani, hiszen egy szerző akár több cikket is írhat, illetve egy cikknek több társszerzője is lehet, de ugyanakkor a FOLYÓIRAT és a CIKK között csak egy-a-többhöz kapcsolat lehet, hiszen egy adott publikáció csak egyszer jelenhet meg a folyóiratban (normál esetben), másrészt egy folyóiratszám több cikket is tartalmazhat.

5. A megfelelő típusú elem megválasztása: A valóság leírása többféle módon lehetséges, így például előfordulhat, hogy a valóság egy szeletét leírhatjuk egyedhalmazzal, attribútummal vagy kapcsolattal is. Általában jellemzö, hogy attribútumokat könnyebb a modellbe bevinni, mint egyedhalmazt, vagy kapcsolatot, ugyanakkor, ha minden attribútummal oldunk meg, az nem minden esetben célszerü, a kész adatbázis kezelését nehézkessé teheti (Példaként lásd: 2. ábra).

\subsection{Az egyed-kapcsolat modell}

Peter Pin-Shan Chen 29 évesen korában megjelentett „The Entity-Relationship Model - Toward a Unified View of Data" címü cikkével (Chen, 1976) megalkotta az egyed-kapcsolat (Entity-Relationship, röviden ER) modell alapjait és ezzel jelentős, máig tartó hatást gyakorolt az adatmodellezésre. Az ER-modell a koncepcionális adatmodellezés legnépszerübb eszközének tekinthető (Hartmann, 2003); népszerüsége az egyszerüség mellett az elméleti megalapozottságnak és annak is köszönhető, hogy a - mai adatbáziskezelő rendszerek által használt relációs adatmodell előkészítésére kiválóan alkalmas. Az előbbiekből következően számos felsőoktatási intézményben tanítják az ER-modellt, ez pedig szintén hozzájárul népszerüségéhez, elterjedtségéhez (Carte et al., 2006).

A modellben az adatok szerkezetének ábrázolására ún. egyed-kapcsolat diagramot (Entity-Relationship Diagram, ERD) használunk (Ulman-Widom, 2009). Az ERD egy gráf, ahol a csúcspontok a modell három alapvető eleme (1) az egyedhalmaz(ok) (téglalappal jelöljük), (2) az attributum(ok) (tulajdonságok) (ellipszissel adjuk meg) és (3) a kapcsolatok (rombusszal jelöljük) (Silberschatz et al., 1996; Tímár et al., 1997; Szabó, 2013). Az egyedhalmazokat az attribútumaikkal és a kapcsolataikkal vonalak segítségével kötjük össze, ezek a gráf élei. (UlmanWidom, 2009). 
Az ER-modell tehát kifejező, egyszerü (nem szakemberek is viszonylag könnyen megérthetik), kevés fogalmat használ ('így gyorsan megtanulható), szemléletes ábrákkal dolgozik, de az alkalmazott ábrázolási mód miatt a nagyon összetett adatbázisok leírása nehézkessé, az elkészült ábra pedig nehezen felfoghatóvá válhat (Dunn et al., 2005).

Az ER-modell elemkészlete:

1. Az egyed egy névvel ellátható (fónévvel megnevezhetö), valamilyen típusú absztrakt objektum; a hasonló egyedek egyedhalmazt alkotnak (például: folyóirat, cikk, szerzö). (Ulman-Widom, 2009).

2. Az attribútum az egyedhalmazhoz, vagy kapcsolathoz tartozik, annak tulajdonságát, tulajdonságait írja le (például: szerző esetében: név, tudományos fokozat, munkahely, neme). (Ulman-Widom, 2009) Egy egyedhalmaznak legalább egy attribútummal kell rendelkeznie, míg a kapcsolathoz nem kötelező attribútumo(ka)t hozzárendelni. Az egyedtípushoz hasonlóan főnevet szokás használni az attribútum megnevezésekor (Tímár et al., 1997); fajtái:

- egyszerü (ellipszis egyszeres vonallal),

- összetett (több részattribútumra bontható, amelyeket az egyszeres vonallal rajzolt ellipszisben jelölünk),

- többértékü (kettős vonallal rajzolt ellipszis) és

- leszármaztatott (szaggatott vonallal rajzolt ellipszis; más tulajdonságok értékeiből számolható - de azt nem jelöljük a modellben, hogy hogyan) (Hampel-Heves, 2019).

3. A kapcsolat két - vagy akár több - egyedhalmazt kapcsol össze egymással és igét használunk a leírására. Két egyedhalmaz összekapcsolása esetén bináris kapcsolatról beszélünk, ez a leggyakoribb. A modell nem zárja ki akár tetszőleges számú egyedhalmaz összekapcsolását sem. (UlmanWidom, 2009).

Dey és munkatársai (1999) vizsgálatai szerint az egyedhalmazok és attribútumaik értelmezése többnyire nem okoz sok gondot a modell felhasználói számára, ugyanakkor a kapcsolatok értelmezésére ez már nem mondható el.

A kapcsolatok típusai lehetnek (Tímár et al., 1997; Dey et al. 1999; UlmanWidom, 2009):

- rekurzív (visszaható, önmagára hivatkozó),

- 1:1 (egy-egy, egy-az-egyhez),

- $\quad$ 1:N (egy-több, egy-a-többhöz),

- N:M (több-több, több-a-többhöz),

- illetve nem bináris, több egyedhalmazt összekötő kapcsolatok esetén az egyedhalmazok számától függően beszélhetünk n-ed fokú (n: az egyedhalmazok száma) kapcsolatról.

Minden felsorolt kapcsolat emellett lehet totális (teljes) és parciális (részleges, opcionális). Totális a kapcsolat akkor, ha minden egyed részt vesz a kapcsolatban és parciális kapcsolatról akkor beszélünk, ha van olyan egyed, amelynek nincs kapcsolata a másik egyedtípus valamelyik egyedéhez (Dullea et al., 2003). 
A modellben fontos szerepet játszik a kulcs attribútum. Minden egyedhalmaznak kell legyen kulcsa (Ulman-Widom, 2009); amit az ERD-on az attribútum megnevezésének aláhúzásával jelölünk. Erről sokan megfeledkeznek a modell elkészítésekor és ebben az adatbázis-kezelő programok is „hibásak”: engedik kulcs nélküli adatbázisok létrehozását (aminek persze oka lehet az egyszerü - egytáblás adatbázisok létrehozásának és kezelésének egyszerüsítése is). A kulcs olyan attribútum, amely alkalmas arra, hogy egyértelmủen azonosítson egy egyedet. Amennyiben több olyan attribútumunk is van, amely alkalmas a célra, akkor egyet kiválasztunk, ez lesz az elsődleges kulcs, a többi pedig alternatív kulcs. Előfordulhat, hogy egy attribútummal önmagában nem azonosítható egy egyed, hanem a minimálisan szükséges több attribútum összevonásával (egyesítésével) kaphatjuk meg az egyértelmủ azonosításra alkalmas összetett kulcsot. Abban az esetben, ha egy egyedhalmaz kulcsában szereplő attribútumok között van olyan, amelyik más egyedhalmazok attribútuma, akkor gyenge egyedhalmazról beszélünk és ezt a tényt dupla vonallal jelöljük (Ulman-Widom, 2009).

A fent leírt ER-modellnek születtek bővített változatai is (Enhanced ER-model, EER-modell, kiterjesztett egyed-kapcsolat modell), amelyek további lehetőségekkel egészítik ki a modell valóságot leíró képességét, így például bevezetnek fö- és alosztályokat, az általánosítás és specializáció fogalmakat (Tímár et al., 1997; Ulman-Widom, 2009), ezeknek azonban a megvalósítani kívánt adatbázis szempontjából nincs lényeges szerepük.

Meg kell jegyezni azt is, hogy az ER-diagramok ábrázolásának többféle variánsa él egymás mellett (Hartmann, 2003), amelyek elsősorban a kapcsolatok ábrázolásában és azok milyenségében térnek el egymástól (Chua-Storey, 2011), lásd: 1. táblázat. Watson véleménye szerint azonban nem az ábrázolás módja számít elsősorban, hanem a helyes modellezési képességet kell elsajátítani (Watson, 2006).

\section{1. táblázat: Két adatmodellezési „dialektus”}

\begin{tabular}{|l|l|c|}
\hline Kapcsolat & Minimalista & DB Visual Architect \\
\hline $1: 1$ & + & +---+ \\
\hline $1: 1$ gyenge egyedtípussal & + & + \\
\hline $1: \mathrm{N}$ & + & $+--0<$ \\
\hline $1: \mathrm{N}$ gyenge egyedtípussal & + & + \\
\hline
\end{tabular}

Forrás: Saját szerkesztés Watson (2006) alapján

\section{Az elkészültt ER-modell}

Az igények összegyüjtése, átgondolása során egy olyan ER-modell született, ami egyetlen egyedtípusban és a hozzá kapcsolt attribútumokban foglalja össze azokat az információkat, amelyeket az adatbázisból ki kellene nyerni. Ez a verzió folyóiratszámonként tartalmaz összesített adatokat, tehát egy-egy számon belül alapadatok (például a szerzők nevének tárolására) nem alkalmas.

Az egyedhalmaz neve: FOLYÓIRAT. Az attribútumokat, a típusukat és a hozzájuk tartozó metaadatokat az alábbi felsorolás tartalmazza a következő 
formátumban: attribútum megnevezése; attribútum típusa; metaadatok és egyéb megjegyzések. A könnyebb áttekinthetőség érdekében az attribútumok elnevezésére több szóból álló kifejezéseket használtam. Ne felejtsük, hogy az attribútumok adatai egy-egy teljes folyóiratszámra vonatkoznak!

1. Azonosító; Összetett tulajdonság; Az egyes folyóiratszámok azonosítására szolgál.

2. Évfolyam; Egyszerü tulajdonság, az Azonosító résztulajdonsága; A folyóirat évfolyama sorszámmal.

3. Szám; Egyszerủ tulajdonság, az Azonosító résztulajdonsága; A folyóirat sorszáma az évfolyamon belül.

Az Évfolyam és a Szám együtt összetett kulcs (aláhúzással jelölve), ami egyértelmủen azonosít egy adott folyóiratszámot.

4. Év; Egyszerü tulajdonság; A folyóirat megjelenésének éve.

5. IsbnIssn; Többértékü tulajdonság; A kiadvány ISBN, illetve ISSN számai. A nyomtatott és az online változat külön ISSN számmal rendelkezik, így egy folyóiratszám esetében egyszerre akár több értéket is felvehet.

6. Kiadó; Egyszerü tulajdonság; A felelös kiadó neve (és szükség esetén egyéb adatai). Ez az attribútum lehet akár összetett tulajdonság is (név, tudományos fokozat, beosztás stb. résztulajdonságokra felbontva), ha van erre igény ezen részadatok külön tárolására információkinyerés céljából.

7. Főszerkesztő; Többértékü tulajdonság; A főszerkesztő vagy szerkesztő pozíciót egyszerre többen is betölthetik.

8. FelelősSzerkesztő; Egyszerű tulajdonság; A felelős szerkesztő neve (és egyéb adatai, ha szükséges).

9. TechSzerkesztő; Többértékủ tulajdonság; Egy számnak egyszerre több technikai szerkesztője lehet.

10. Oldalszám; Egyszerü tulajdonság; Az adott folyóiratszám teljes oldalszáma, nem csak a cikkeké.

11. Témakör; Egyszerü tulajdonság; A témakörök darabszáma.

12. Cikk; Egyszerü tulajdonság; A tudományos cikkek darabszáma.

13. EgySzerző; Egyszerü tulajdonság; Az egyszerzős cikkek darabszáma.

14. KétSzerző; Egyszerü tulajdonság; A két társszerzővel rendelkező cikkek darabszáma.

15. TöbbSzerző; Egyszerü tulajdonság; A legalább három társszerzővel rendelkező cikkek darabszáma.

16. MagyarCikk; Egyszerü tulajdonság; A magyar nyelvü cikkek száma egy adott folyóiratszámban.

17. IdegenCikk; Egyszerü tulajdonság; Az idegen nyelvű cikkek száma.

18. Szerző; Egyszerü tulajdonság; A szerzők száma folyóiratszámonként.

19. MKSzerző; Egyszerü tulajdonság; Azoknak a szerzőknek a száma, akik az Mérnöki Kar dolgozói.

20. MKSzteSzerző; Egyszerü tulajdonság; Azoknak a szerzőknek a száma, akik nem a Mérnöki Kar dolgozói. 
21. Fokozat; Egyszerü tulajdonság; A tudományos fokozattal rendelkező szerzők száma.

22. MagyarSzerző; Egyszerü tulajdonság; A neve alapján magyar szerzők száma (mivel állampolgársági adatok nem állnak rendelkezésre).

23. IdegenSzerző; Egyszerü tulajdonság; A nem magyar (hangzású) szerzők száma.

24. Férfi; Egyszerü tulajdonság; A nevük alapján férfi szerzők száma.

25. Nő; Egyszerü tulajdonság; A nevük alapján nő szerzők száma.

Látható, hogy ez az egy egyedhalmazból és huszonöt attribútumból álló ERmodell számos információ kinyerésére alkalmas, ugyanakkor sok előkészítést, elözetes manuális összesítést igényel, ráadásul fontos alapadatokat (például szerzők neve, cikkek címe) - amelyek lehetővé tennék további információk kinyerését - nem tartalmaz. A modell diagramja látható a 2. ábrán.

\section{2. ábra: A folyóirat ER-diagramja (1. változat)}

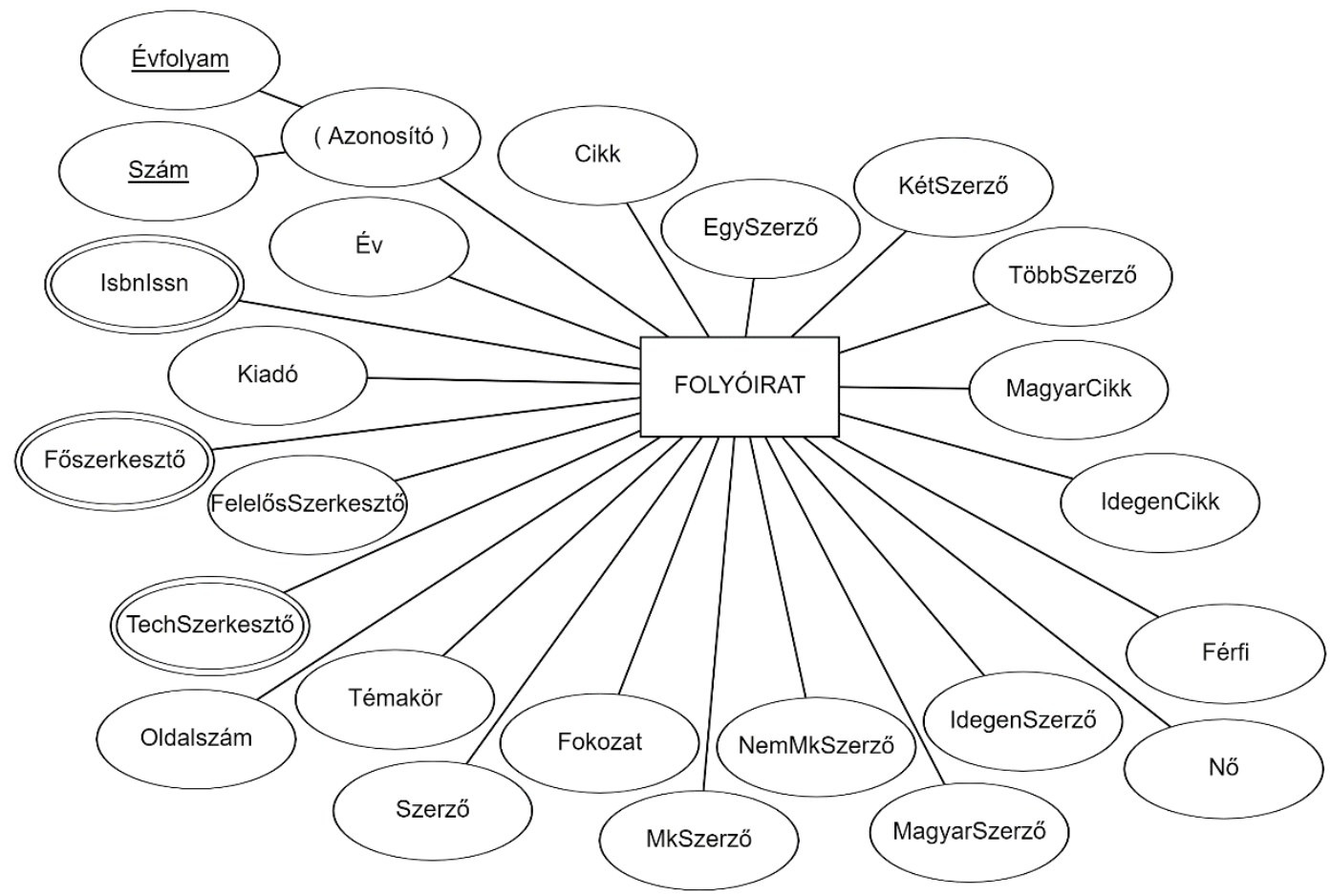

Forrás: Saját szerkesztés. Az ERD az erdplus.com adatmodellező weboldal eszközeivel készült.

Az ER-modell első változatát áttekintve készült a második, véglegesnek tekintett modell. A modell három egyedhalmazt (FOLYÓIRAT, CIKK, SZERZÖ) tartalmaz attribútumokkal, valamint három kapcsolatot (Ír, Publikál, Tartalmaz). A modell leírását, az attribútumokat, a típusukat és a hozzájuk tartozó metaadatokat az alábbi felsorolás tartalmazza attribútum megnevezése; attribútum típusa; metaadatok és egyéb megjegyzések formában.

A FOLYÓIRAT attribútumai: 
1. Évfolyam; Egyszerü tulajdonság; A folyóirat évfolyama sorszámmal.

2. Szám; Egyszerü tulajdonság; A folyóirat sorszáma az évfolyamon belül.

Az Évfolyam és a Szám együtt összetett kulcs (aláhúzással jelölve).

3. Év; Egyszerü tulajdonság; A folyóirat megjelenésének éve.

4. IsbnIssn; Többértékủ tulajdonság; A kiadvány ISBN, illetve ISSN számai.

5. FelelősKiadó; Egyszerü tulajdonság; A felelős kiadó neve (és szükség esetén egyéb adatai).

6. Föszerkesztő; Többértékü tulajdonság; A föszerkesztő(k) vagy szerkesztő(k) neve (és egyéb adatai).

7. FelelősSzerkesztő; Egyszerü tulajdonság; A felelős szerkesztő neve (és egyéb adatai).

8. TechSzerkesztő; Többértékü tulajdonság; A technikai szerkesztő neve (és egyéb adatai).

9. Oldalszám; Egyszerü tulajdonság; Egy adott folyóiratszám teljes oldalszáma.

10. ÖsszesOldalDb; Leszármaztatott tulajdonság; Az folyóiratok oldalszáma összesen (az OldalSzám végösszege, a modell a számítás módját nem jelöli).

A CIKK attribútumai:

1. CikkCím; Egyszerü tulajdonság és elsődleges kulcs; Mivel a cikk címe elsődleges kulcs, nem lehet két azonos című cikk az adatbázisban.

2. Szekciónév; Egyszerü tulajdonság; A szekció neve (ha van), amelybe a cikk tartozik.

3. Oldalkezd; Egyszerü tulajdonság; A cikk kezdő oldalszáma.

4. OldalVégső; Egyszerü tulajdonság; A cikk utolsó oldalának oldalszáma.

5. Nyelv; Egyszerü tulajdonság; A cikk nyelve.

6. KulcsszóMagyar; Többértékü tulajdonság; A cikkhez tartozó magyar kulcsszavak.

7. KulcsszóAngol; Többértékü tulajdonság; A cikkhez tartozó angol kulcsszavak.

8. ForrásSzám; Egyszerü tulajdonság; A cikkhez tartozó források darabszáma.

9. CikkOldalSzámDb; Leszármaztatott tulajdonság;

10. CikkSzámDb; Leszármaztatott tulajdonság; A cikkek darabszáma.

11. SzekcióDb; Leszármaztatott tulajdonság; A szekciók darabszáma.

12. NSzerzőDb; Leszármaztatott tulajdonság; Az N-számú szerzők által írt cikkek száma.

13. MagyarCikkDb; Leszármaztatott tulajdonság; A magyar cikkek darabszáma.

14. IdegenCikkDb; Leszármaztatott tulajdonság; Az idegen nyelvü cikkek darabszáma.

15. MkCikkDb; Leszármaztatott tulajdonság; A Mérnöki Karon dolgozó szerzők cikkeinek darabszáma.

16. NemMkCikkDb; Leszármaztatott tulajdonság; A nem Mérnöki Karon dolgozó szerzők cikkeinek darabszáma.

A SZERZÖ attribútumai: 
Alaposan végig kell gondolni, hogy az egyes szerzőket milyen tulajdonság(ok) alapján lehet azonosítani. A név önmagában nem elegendő, hiszen előfordulhat, hogy két vagy több különböző szerzőnek ugyanaz a neve, illetve, ha valaki nevet változtat két publikálás közben, akkor ő két névvel fog szerepelni és emiatt két különböző személynek fog számítani. A név, a fokozat (és munkahely) tulajdonságok összevonásával sem jutunk elörébb: ha egy többször publikáló szerző (új) tudományos fokozatot szerez, vagy munkahelyet vált, akkor megint csak két különböző személynek fog számítani. A probléma kezelhető egy önkényesen létrehozott egyedi azonosítóval, ami használható kulcstulajdonságként.

1. SzerzőAzonosító; Egyszerü tulajdonság; A szerzők egyértelmű azonosítását szolgáló kulcstulajdonság.

2. SzerzőNeve; Egyszerü tulajdonság; Mivel elvileg előfordulhat, hogy két vagy akár több szerzőnek ugyanaz a neve, ezért - bár kényelmes megoldás lenne - önmagában nem lehet kulcstulajdonság.

3. Fokozat; Többértékü tulajdonság; A szerző (tudományos) fokozata, amikor a cikket írta. Előfordulhat, hogy egy szerző több számban is publikál és közben új tudományos fokozatot szerez.

4. Munkahely; Többértékü tulajdonság; A szerző munkahelyének adatai, amely lehet akár összetett tulajdonság is, hogy részeire bontható legyen (ha erre a későbbiekben lesz igény). Előfordulhat, hogy egy szerző több számban is publikál és közben munkahelyet vált.

5. Neme; Egyszerü tulajdonság; A szerző neme a neve alapján.

6. SzerzőFő; Leszármaztatott tulajdonság; A szerzők száma összesen.

7. FokozatFő; Leszármaztatott tulajdonság; A tudományos fokozattal rendelkező szerzők száma.

8. MagyarSzerzőFő; Leszármaztatott tulajdonság; A magyar nevü szerzők száma.

9. IdegenSzerzőFő; Leszármaztatott tulajdonság; A nem magyar nevű szerzők száma.

10. MkSzerzőFő; Leszármaztatott tulajdonság; A Mérnöki Kar szerzőinek száma.

11. NemMkSzerzőFő; Leszármaztatott tulajdonság; Azoknak a szerzőknek a száma, akik nem a Mérnöki Karon dolgoznak.

12. NőFő; Leszármaztatott tulajdonság; A nevük alapján nő szerzők száma.

13. FérfiFö; Leszármaztatott tulajdonság; A nevük alapján férfi szerzők száma. A kapcsolat jellemzöi:

- 1 számban több szerző publikálhat, 1 szerző több számban publikálhat, 1 cikk csak 1 számban jelenhet meg.

- Minden szerzőnek publikálnia kell valamelyik számban: egy szerzőnek kell legyen legalább 1 kapcsolata egy cikkhez és több cikkhez is lehet; egy szerzőnek kell legyen legalább 1 kapcsolata egy folyóiratszámhoz és több folyóiratszámhoz is lehet. 
- Minden cikket publikálni kell valamelyik számban: egy cikknek 1 és csak 1 kapcsolata lehet a folyóirathoz; egy cikknek kell legyen legalább 1 kapcsolata egy szerzöhöz és több szerzőhöz is lehet.

- Minden folyóiratszámban kell legyen szerző: egy folyóiratszámnak kell legyen legalább 1 kapcsolata 1 szerzőhöz és több szerzőhöz is lehet.

- Minden folyóiratszámban kell legyen cikk: egy folyóiratszámnak kell legyen legalább 1 kapcsolata egy cikkhez.

- Az elöbbiekből következően minden kapcsolat totális. A FOLYÓIRAT és a SZERZÖ között, valamint a SZERZÖ és a CIKK között több-a-többhöz (N:M) kapcsolatot, míg a CIKK és a FOLYÓIRAT között egy-a-többhöz (1:N) kapcsolatot kell létrehozni.

Az elkészült koncepciós modell diagramját a 3. ábra tartalmazza. Az elsőre egyszerünek (és gyorsan végrehajthatónak) tünő feladat szisztematikus végiggondolása (mit vegyünk fel egyedhalmazként, mik legyenek az attribútumok, milyen jellegü kapcsolat szükséges az egyedhalmazok között) segített a helyes - a valóságot a megoldandó feladat szempontjából megfelelően leíró - adatbázis koncepciós modelljének létrehozásában.

\section{3. ábra: A folyóirat ER-diagramja (2. változat)}

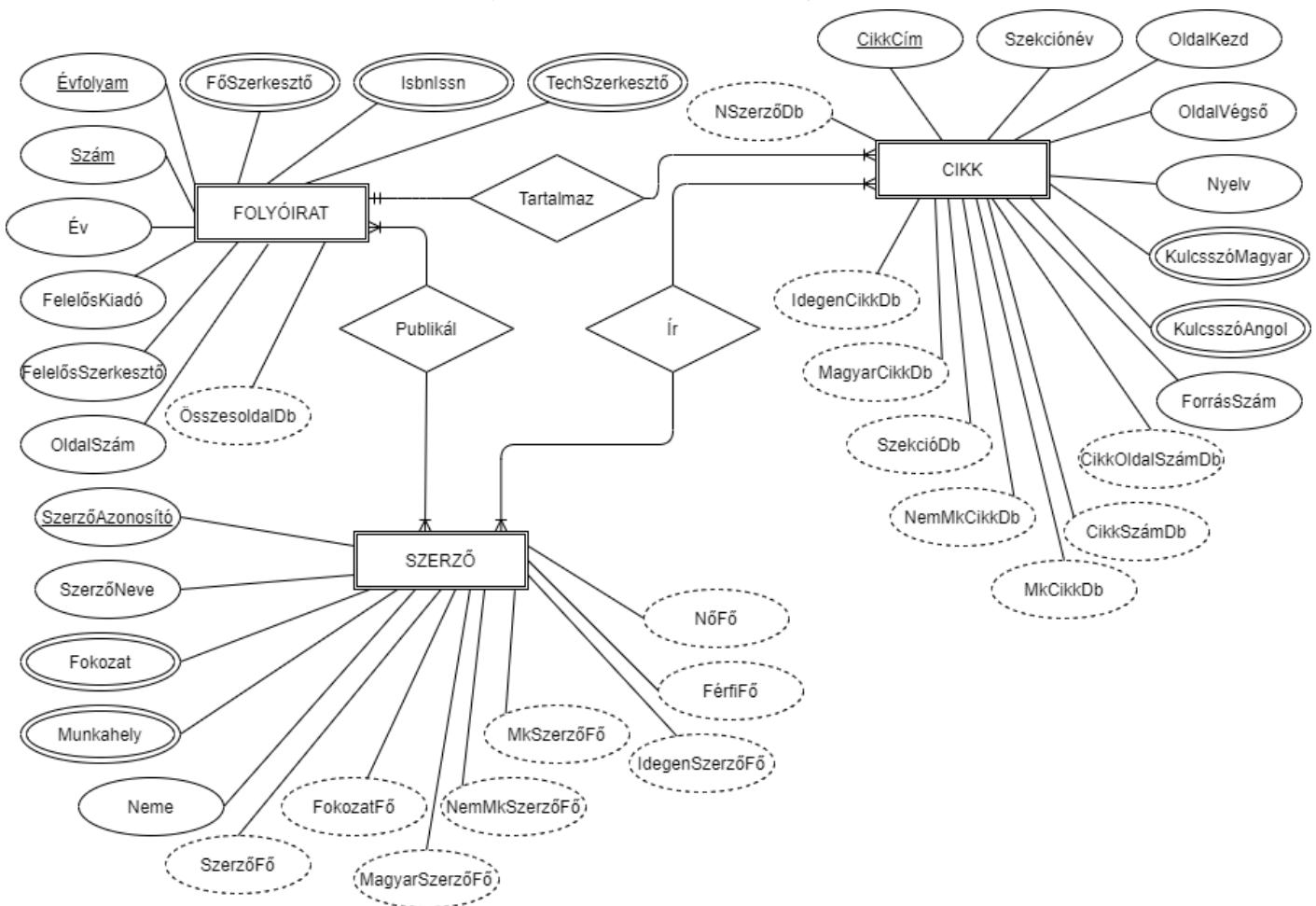

Forrás: saját szerkesztés. Az ERD a diagrams.net weboldal eszközeivel készült.

\section{Záró gondolatok}

A létrehozott ER-modell jelenlegi formájában alkalmas a megvalósításra, de ez nem zárja ki azt, hogy újabb ötleket ad a szerkesztőbizottságnak további információk 
kinyerésére, ami miatt további kiegészítésre, módosításra lehet szükség még a logikai tervezést megelőzően.

A munka következő fázisa a koncepciós modell átültetése logikai szintre, azaz a relációs modell létrehozása. Ebben a lépésben kell az egyedhalmazokat, az attribútumokat és a kapcsolatokat átkonvertálni táblákat, és azok szerkezetét, valamint a táblák közötti kapcsolatot leíró relációs sémává.

A befejező fázis a fizikai megvalósítás lesz, ami a relációs séma SQL-alapú megvalósítását jelenti a kiválasztott relációs adatbázis-kezelő rendszerben.

Amennyiben a későbbiekben lesz rá igény, az elkészült adatbázist akár szövegbányászatra is alkalmassá lehet fejleszteni és ebben az esetben az még eredményesebben járulhat hozzá a „Jelenkori társadalmi és gazdasági folyamatok” címü folyóiratban rejlő tudás kiaknázásához.

\section{Irodalomjegyzék}

Badia, A., Lemire D. (2011): A Call to Arms: Revisiting Database Design. Sigmod Record, 40 (3): 61-69. https://doi.org/10.1145/2070736.2070750

Carte, T. A., Jasperson, J., Cornelius, M. E. (2006): Integrating ERD and UML Concepts When Teaching Data Modeling. Journal of Information Systems Education, 17 (1): 55-63.

Chen P. P.-Sh. (1976): The Entity-Relationship Model - Toward a Unified View of Data. ACM Transactions on Database Systems, 1 (1): 9-36. https://doi.org/10.1145/320434.320440

Chua, C. E. H., Storey, V. C. (2011): Issues and Guidelines in Modeling Decomposition of Minimum Participation in Entity-Relationship Diagrams. Communications of the Association for Information Systems, 29 (9): 159-184. https://doi.org/10.17705/1CAIS.02909

Dey, D., Storey, V., Terence, B. (1999): Improving Database Design Through the Analysis of Relationships. ACM Transactions on Database Systems, 24 (4): 453-486. https://doi.org/10.1145/331983.331984

Dullea, J., Song, Il-Y., Lamprou, I. (2003): An Analysis of Structural Validity in Entity-Relationship modeling. Data \& Knowledge Engineering, 47 (2): 167-205. https://doi.org/10.1016/S0169023X(03)00049-1

Dunn, Ch. L., Gerard, G. J., Grabski, S.V. (2005): Critical Evaluation of Conceptual Data Models. International Journal of Accounting Information Systems, 6 (2): 83-106. https://doi.org/10.1016/j.accinf.2004.03.002

Gulyás L. (2006): Elöszó. Jelenkori gazdasági és társadalmi folyamatok, 1 (1): 1.

Gulyás L., Gál J. (2007): Előszó. Jelenkori gazdasági és társadalmi folyamatok, 2 (1): 4.

Gulyás L., Gál J. (2008): Előszó. Jelenkori gazdasági és társadalmi folyamatok, 3 (1): 4.

Gulyás L., Gál J. (szerk.) (2009):Borítólap. Jelenkori gazdasági és társadalmi folyamatok, 4 (1).

Halassy B. (1994): Az adatbázis-tervezés alapjai és titkai. IDG Magyarországi Lapkiadó Kft., Budapest.

Halassy B. (1994): Adatmodellezés. Elmélet és gyakorlat. Budapest. <https://mek.oszk.hu/11100/11144> (2020. 08.10.)

Hampel Gy., Heves Cs. (2019): Informatika alapjai mérnököknek, alapszakos hallgatók számára. Szegedi Tudományegyetem, Szeged.

Hartmann, S. (2003): Reasoning about participation constraints and Chen's constraints. Database Technologies 2003, Proceedings of the 14th Australasian Database Conference, ADC 2003, Adelaide, South Australia, February 2003: 105-113.

Kacsukné B. L., Kiss T. (2009): Bevezetés az üzleti informatikába. Akadémiai Kiadó, Budapest.

Kis K. (szerk.) (2020): Belső címlap. Jelenkori gazdasági és társadalmi folyamatok, 15 (1-2): 1.

Kovács L. (2004): Adatbázisok tervezésének és kezelésének módszertana. Computer Books, Budapest. 
Kroenke, D. M. (2006): Toward a Next Generation Data Modeling Facility: Neither the EntityRelationship Model nor UML Meet the Need. Journal of Information Systems Education, 17 (1): 29-38.

Lendvai E., Koppány K. (2018): Kvalitatív vizsgálat a Kígyóscsili termékeinek fogyasztói körében. Jelenkori gazdasági és társadalmi folyamatok, 13 (3-4): 71-77.

Panyor Á., Szebelédi K. (2018): A termelői értékesítő szervezetek szerepe a vidék gazdaságában. Jelenkori gazdasági és társadalmi folyamatok, 13 (3-4): 33-42.

Silberschatz, A., Korth, H. F., Sudarshan, S. (1996): Data Models. ACM Computing Surveys, 28 (1): 105-108. https://doi.org/10.1145/234313.234360

Szabó B. (2013): Adatbázis fejlesztés és üzemeltetés I. Eszterházy Károly Főiskola, Eger.

Tímár L., Vígh K., Tátrai J., Szigeti J., Vathy Á., Telekesi É., Vass I., Kocsis T., Priskinné R. Zs., Erdélyiné M. (19997): Épitsünk könnyen és lassan adatmodellt! Veszprémi Egyetem \& Müszertechnika-Veszprém Kft., Veszprém.

Ullman, J., Widom, J. (2008): Adatbázisrendszerek - Alapvetés. Panem Kiadó, Budapest.

Watson, R. T. (2006): The Essential Skills of Data Modeling. Journal of Information Systems Education, 17 (1): 39-41.

Zsótér B., Bagi B. (2020): Gyümölcsfeldolgozó üzem létesítésének pénzügyi elökészületei. Jelenkori gazdasági és társadalmi folyamatok, 15(1-2): 131-134. 